\title{
THE ELECTROCARDIOGRAM DURING EXCHANGE TRANSFUSION
}

\author{
BY \\ A. ROBINSON* and HERBERT BARRIE \\ From the Children's Department, St. Thomas's Hospital, London
}

(RECEIVED FOR PUBLICATION NOVEMBER 16, 1962)

Exchange transfusion is a hazardous procedure with a mortality of $4-7.5 \%$ (van Praagh, 1961; Boggs and Westphal, 1960). Various complications may lead to sudden death in which hyperkalaemia, hypocalcaemia, acidosis, citrate toxicity, circulatory overloading, hypothermia and embolism have been incriminated (Farquhar and Smith, 1958). The mode of death in these cases, whatever the aetiology, is usually acute cardiac failure.

This account is based on three years' experience in electrocardiographic monitoring of the heart during exchange transfusion.

\section{Material and Method}

Thirty electrocardiograms were obtained during exchange transfusions on 27 infants (Table 1). Ten of the babies weighed under $2,500 \mathrm{~g}$. and the smallest baby in the series weighed $790 \mathrm{~g}$. on the day of transfusion. Erythroblastosis due to rhesus incompatibility was the commonest indication for exchange transfusion ( 23 cases), three had hyperbilirubinaemia of prematurity and there was one case of ABO incompatibility. Elective caesarian section or induction of labour before term was performed in the presence of high or rising maternal antibody titres (Tovey and Valaes, 1959). Three babies died: one with haemolytic disease was severely affected at birth (haemoglobin $3.7 \mathrm{~g} . / 100 \mathrm{ml}$.), one died of cardiac failure 18 hours after an uneventful exchange transfusion and one died six days after a difficult exchange transfusion (see below).

The technique of exchange transfusion was essentially that described by Allen and Diamond (1957). The umbilical vein was cannulated with a polythene catheter passed as far as the inferior cava. Venous pressures were measured at the beginning, during and end of the procedure. The exchange was begun after an initial withdrawal of $20-50 \mathrm{ml}$. and the infant was usually left with a negative balance of $10-30 \mathrm{ml}$. Babies over $5 \mathrm{lb}$. $(2 \cdot 26 \mathrm{~kg}$.) were exchanged in $20 \mathrm{ml}$. cycles, and those under $5 \mathrm{lb}$. $(2 \cdot 26 \mathrm{~kg}$.) in $10 \mathrm{ml}$. cycles; $5 \mathrm{ml}$. cycles were

* Present address: St. Bartholomew's Hospital, London. used in the smallest baby. The donor blood was less than three days old and packed by the removal of $80-90 \%$ of the plasma irrespective of the indication for exchange transfusion. A full minute was taken over each injection and the overall rate of exchange was regulated so as not to exceed $5 \mathrm{ml}$. per minute. The amount transfused was calculated on the basis of $80 \mathrm{ml}$. per $\mathrm{lb}$. One $\mathrm{ml}$. of $10 \%$ calcium gluconate was injected slowly after every 100 to $150 \mathrm{ml}$. of blood exchanged. Digoxin was given routinely in only the first two cases. Special care was taken to avoid chilling and in most of the premature babies the procedure was performed in an incubator.

A direct writing electrocardiograph was connected to the infant throughout the procedure. The instruments used were the Cardioluxe (Phillips Electrical Ltd.) and the Electrite (Cambridge Instrument Co.). Standard and unipolar limb leads were recorded before starting transfusion and the lead showing the clearest configuration of all parts of the complex was then selected for monitoring. Heart rates were taken every five minutes by counting the deflections of the stylus and a short record taken every 10 to 15 minutes by a student or nurse, who also noted the amounts of blood injected and withdrawn.

\section{Results}

The findings are summarized in Tables 2 and 3.

Rate and Rhythm. Variations in rate between 110 and 160 per minute were not uncommon, but in two-thirds of the babies the rates before and after the procedure were the same. The record with the fastest initial rate of 168 per minute (Fig. 1), occurred in a baby who subsequently collapsed during the transfusion. Only three babies developed bradycardia of under 100 per minute; two of these also had abnormal complexes and one died. Slight slowing after injection of calcium gluconate was recorded in five babies. Marked slowing from 166 to 100 per minute was produced in one baby by a deliberately rapid injection of $10 \mathrm{ml}$. of blood in six seconds (Fig. 2). 
TABLE 1

THIRTY CONSECUTIVE EXCHANGE TRANSFUSIONS

\begin{tabular}{|c|c|c|c|c|c|c|}
\hline \multirow{2}{*}{$\begin{array}{l}\text { Case } \\
\text { No. }\end{array}$} & \multirow{2}{*}{$\begin{array}{c}\text { Birth } \\
\text { Weight } \\
\text { (kg.) }\end{array}$} & \multirow{2}{*}{$\underset{\text { (g. } / 100 \mathrm{ml} .)}{\stackrel{\text { Initial }}{\mathbf{H b}}}$} & \multicolumn{2}{|c|}{ Exchange (ml.) } & \multirow{2}{*}{$\begin{array}{c}\text { Duration } \\
\text { (min.) }\end{array}$} & \multirow{2}{*}{ Remarks } \\
\hline & & & Total Out & Total In & & \\
\hline $\begin{array}{l}1 \\
2 \\
3\end{array}$ & $\begin{array}{l}2 \cdot 53 \\
3 \cdot 54 \\
3 \cdot 27\end{array}$ & $\begin{array}{r}9 \cdot 0 \\
12 \cdot 9 \\
16 \cdot 9\end{array}$ & $\begin{array}{l}565 \\
530 \\
550\end{array}$ & $\begin{array}{l}550 \\
520 \\
550\end{array}$ & $\begin{array}{r}90 \\
90 \\
120\end{array}$ & $\begin{array}{l}\text { Uneventful } \\
\text { Uneventful } \\
\text { Diabetic mother-lower segment caesarian section } \\
\text { Respiratory distress and cyanotic attacks }\end{array}$ \\
\hline $\begin{array}{l}4 \\
5 \\
6(\mathrm{i}) \\
(\mathrm{ii}) \\
7 \\
8 \\
9 \\
10 \\
11 \\
12 \\
13 \\
14 \\
15 \\
16 \\
17 \\
18 \\
19\end{array}$ & $\begin{array}{l}3 \cdot 0 \\
3 \cdot 8 \\
3 \cdot 54 \\
3 \cdot 54 \\
3 \cdot 21 \\
2 \cdot 88 \\
2 \cdot 85 \\
3 \cdot 33 \\
3 \cdot 27 \\
3 \cdot 15 \\
3 \cdot 18 \\
4 \cdot 06 \\
2 \cdot 94 \\
3 \cdot 39 \\
4 \cdot 0 \\
2 \cdot 3 \\
1 \cdot 48\end{array}$ & $\begin{array}{r}8 \cdot 4 \\
15 \cdot 5 \\
6 \cdot 8 \\
14 \cdot 8 \\
13.9 \\
12.0 \\
11 \cdot 0 \\
16 \cdot 0 \\
13 \cdot 0 \\
9 \cdot 2 \\
3.7 \\
12.6 \\
9.2 \\
13.3 \\
7.4 \\
11.8 \\
-\end{array}$ & $\begin{array}{l}510 \\
500 \\
310 \\
310 \\
640 \\
520 \\
510 \\
480 \\
610 \\
470 \\
540 \\
600 \\
550 \\
590 \\
260 \\
300 \\
\text { Notes }\end{array}$ & $\begin{array}{r}440 \\
480 \\
300 \\
280 \\
640 \\
490 \\
510 \\
460 \\
580 \\
440 \\
480 \\
580 \\
510 \\
570 \\
180 \\
290 \\
\text { issing }\end{array}$ & $\begin{array}{r}55 \\
90 \\
50 \\
55 \\
90 \\
75 \\
120 \\
80 \\
90 \\
115 \\
72 \\
120 \\
120 \\
90 \\
65 \\
55 \\
\end{array}$ & $\begin{array}{l}\text { Early cardiac failure } \\
\text { Uneventful } \\
\text { Uneventful; transient systolic murmur } \\
\text { Uneventful } \\
\text { Uneventful } \\
\text { Uneventful } \\
\text { Uneventful } \\
\text { Vomiting and tachycardia } \\
\text { Uneventful } \\
\text { Early cardiac failure } \\
\text { Hydrops; died } \\
\text { Uneventful } \\
\text { Uneventful } \\
\text { Uneventful } \\
\text { Cardiac failure; transfusion abandoned; died } 6 \text { days later } \\
\text { Collapsed after } 39 \text { min.; transfusion abandoned; recovered } \\
\text { Resniratory distress syndrome }\end{array}$ \\
\hline $\begin{array}{l}20 \text { (i) } \\
\text { (ii) } \\
\text { (iii) } \\
21 \\
22 \\
23 \\
24 \\
25 \\
26 \\
27\end{array}$ & $\begin{array}{l}1 \cdot 48 \\
2 \cdot 27 \\
2 \cdot 27 \\
2 \cdot 27 \\
2 \cdot 42 \\
2 \cdot 27 \\
1 \cdot 66^{*} \\
0 \cdot 79 * \\
2 \cdot 15 \\
2 \cdot 76 \\
1 \cdot 2^{*}\end{array}$ & $\begin{array}{r}1 \overline{10 \cdot 0} \\
20 \cdot 1 \\
12 \cdot 5 \\
14 \cdot 1 \\
11 \cdot 8 \\
18 \cdot 5 \\
16 \cdot 2 \\
8 \cdot 9 \\
11 \cdot 8 \\
17 \cdot 2\end{array}$ & $\begin{array}{l}415 \\
\text { Notes } \\
360 \\
350 \\
460 \\
500 \\
370 \\
135 \\
430 \\
440 \\
260\end{array}$ & $\begin{array}{r}\text { 1ssing } \\
405 \\
350 \\
350 \\
440 \\
525 \\
350 \\
140 \\
410 \\
420 \\
240\end{array}$ & $\begin{array}{l}80 \\
75 \\
80 \\
75 \\
90 \\
75 \\
90 \\
90 \\
90 \\
90\end{array}$ & $\begin{array}{l}\text { Respiratory distress syndrome } \\
\text { Uneventful } \\
\text { Uneventful (at } 24 \text { hours) } \\
\text { Uneventful (at } 50 \text { hours) } \\
\text { Uneventful } \\
\text { Uneventful; died of cardiac failure } 18 \text { hours later } \\
\text { Uneventful } \\
\text { Frequent apnoeic attacks; cold and poor condition after } \\
\text { Uneventful } \\
\text { Uneventful } \\
\text { Uneventful }\end{array}$ \\
\hline
\end{tabular}

* Weight on day of exchange transfusion.

TABLE 2

E.C.G. CHANGES IN 30 EXCHANGE TRANSFUSIONS

\begin{tabular}{|c|c|c|c|}
\hline E.C.G & $\begin{array}{l}\text { Normal } \\
\text { (No.) }\end{array}$ & $\begin{array}{l}\text { Abnormal } \\
\text { (No.) }\end{array}$ & Main Changes \\
\hline Rate & 22 & 8 & $\begin{array}{l}\text { Tachycardia- } 40 \% \text { increase and over (5) } \\
\text { Bradycardia-under } 100 / \mathrm{min} \text {. }\end{array}$ \\
\hline $\mathbf{P}$ & 16 & 14 & Prominent \\
\hline QRS & 21 & 9 & $\begin{array}{l}\text { Low voltage } \\
\text { Deep S } \\
\text { Wide or notched (2) }\end{array}$ \\
\hline ST & 25 & 5 & Depressed. \\
\hline $\mathbf{T}$ & 16 & 14 & $\begin{array}{ll}\text { Flat: } & \text { transient }(6) \text {; persistent }(7) \\
\text { High } & (1)\end{array}$ \\
\hline QT & 27 & 3 & Prolonged \\
\hline
\end{tabular}

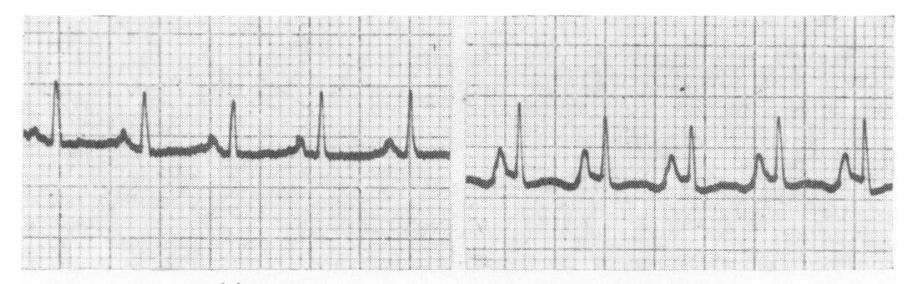

(a)

(b)

Fig 1.-Case 18. Lead II. (a) before and (b) during exchange transfusion. There is initial tachycardia followed by elevation of the $\mathbf{P}$ wave. The changes are consistent with right atrial strain. 
TABLE 3

ELECTROCARDIOGRAM ANALYSIS IN PREMATURE BABIES AND OTHERS OF INTEREST

\begin{tabular}{|c|c|c|c|c|c|c|c|c|c|c|c|c|}
\hline \multirow[b]{2}{*}{ Weight } & \multirow[b]{2}{*}{$\begin{array}{l}\text { Case } \\
\text { No. }\end{array}$} & \multicolumn{2}{|c|}{ Rate } & \multirow{2}{*}{ P } & \multicolumn{3}{|c|}{ QRS } & \multirow{2}{*}{ 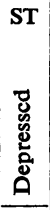 } & \multirow{2}{*}{$\begin{array}{l}\mathbf{T} \\
\stackrel{\mathbb{m}}{\boldsymbol{I}}\end{array}$} & \multicolumn{2}{|c|}{ QT } & \multirow[b]{2}{*}{ Clinical Observations } \\
\hline & & 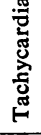 & 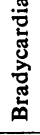 & & 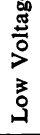 & $\begin{array}{l}2 \\
8 \\
8 \\
8 \\
0\end{array}$ & 总 & & & $\frac{1}{\infty}$ & $\begin{array}{l}\text { 염 } \\
\text { 며 } \\
\text { 음 } \\
\text { م. }\end{array}$ & \\
\hline$>2,500 \mathrm{~g}$ & $\begin{array}{r}4 \\
10 \\
12 \\
13 \\
\\
17\end{array}$ & + & + & + & $\begin{array}{l}+ \\
+\end{array}$ & + & + & $\begin{array}{l}+ \\
+ \\
+\end{array}$ & $\begin{array}{l}+ \\
+\end{array}$ & + & + & $\begin{array}{l}\text { Marked anaemia; Hb } 8.4 \mathrm{~g} . ; \text { early cardiac failure } \\
\text { Vomiting and tachycardia of } 186 / \mathrm{min} \text {. at times } \\
\text { Breathless, cold and limp at end of transfusion } \\
\text { Severe anaemia (Hb } 3.7 \text { g.) and cardiac failure; transfusion } \\
\text { abandoned twice due to bradycardia and apnoeic attack; } \\
\text { died suddenly at end of transfusion } \\
\text { Severe cardiac failure; transfusion abandoned twice due to } \\
\text { heart block on E.C.G.; died } 5 \text { days later with pulmonary, } \\
\text { splenic and renal infarcts }\end{array}$ \\
\hline$<2,500 \mathrm{~g}$ & $\begin{array}{l}18 \\
19 \\
20(\text { i) } \\
\text { (ii) } \\
21 \\
22 \\
23 \\
24 \\
25 \\
26 \\
27\end{array}$ & $\begin{array}{l}+ \\
+\end{array}$ & + & $\begin{array}{l}+ \\
+ \\
+ \\
+ \\
+ \\
+ \\
+ \\
+ \\
+\end{array}$ & + & & & $\begin{array}{l}+ \\
+\end{array}$ & $\begin{array}{l}+ \\
+ \\
+ \\
+ \\
+ \\
+ \\
+\end{array}$ & & + & $\begin{array}{l}\text { Cold and collapsed; transfusion abandoned twice } \\
\text { Respiratory distress syndrome } \\
\text { Uneventful } \\
\text { Uneventful } \\
\text { Uneventful } \\
\text { Uneventful } \\
\text { Uneventful exchange; developed cardiac failure and died } \\
18 \text { hrs. later; acute gastric ulcer found at autopsy } \\
\text { Uneventful } \\
\text { Periodic respiration with frequent apnoea, bradycardia and } \\
\text { cyanosis, reversed by nikethamide and glucose } \\
\text { Uneventful } \\
\text { Uneventful } \\
\text { Uneventful }\end{array}$ \\
\hline
\end{tabular}

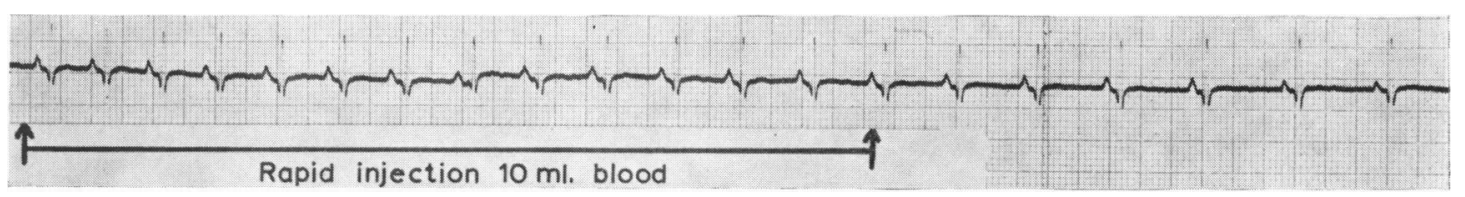

FIG. 2.-Case 2. Lead III. Slowing of the heart due to rapid injection of blood.

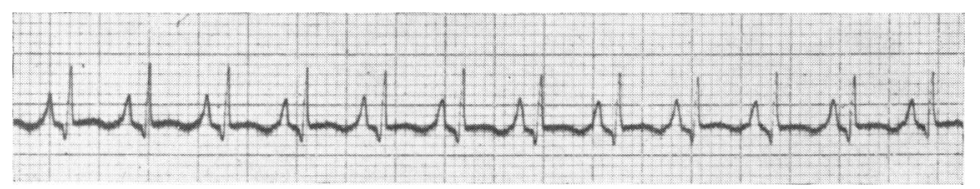

Fig. 3.-Case 20, iii. Lead III. High P waves and tachycardia during exchange transfusion. The changes are consistent with right atrial strain.

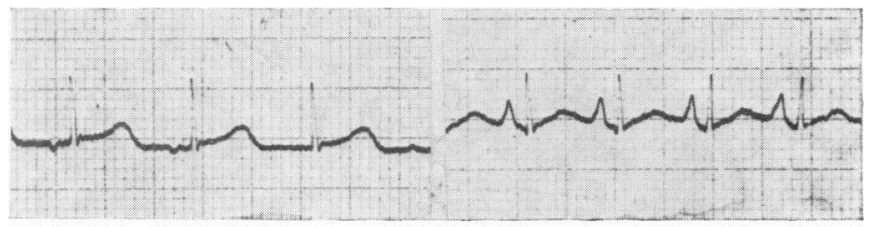

(a)

(b)

Fig. 4.-Case 14. Lead II. (a) before and (b) during crying, showing tachycardia and high $P$ waves. The changes are consistent with increased right atrial pressure. 


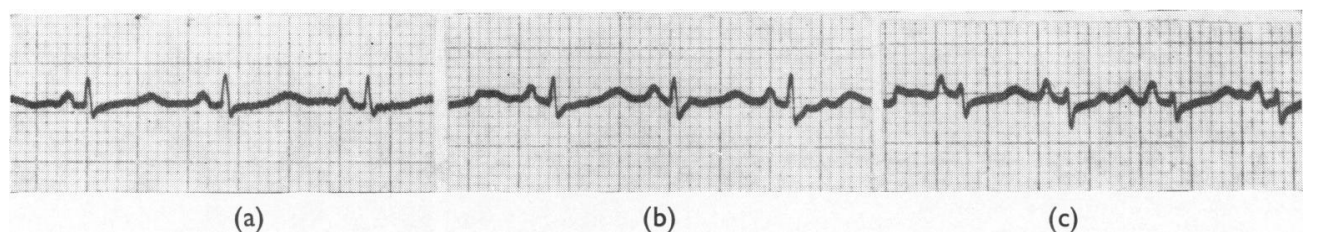

(a)

(b)

(c)

Fig. 5.-Case 12. Lead II. (a) before and (b), (c) during exchange transfusion. There is progressive decrease in the height of the $R$ wave and depression of the ST segment. The changes are consistent with cardiac failure.

P Wave. An increase in the height of the $P$ wave (Fig. 3) was the commonest change encountered and occurred in 14 tracings. This developed soon after beginning the transfusion and was marked in seven cases, but was usually unassociated with any other disturbance. It did not develop during the rapid injection of blood but occurred in other babies during crying (Fig. 4).

P-R Interval. A prolonged P-R interval occurred in only one case as part of a generally abnormal electrocardiogram.

QRS Complex. No change occurred in 16 tracings. A decrease in the height of the $R$ wave occurred in 11 (Fig. 5). Gross changes were recorded in two babies, one of whom died soon after abandoning transfusion and the other six days later (Figs. 6 and 8).

ST Segment. ST depression was recorded in five cases (Figs. 5 and 8). In one with respiratory distress this was present before beginning the transfusion and was probably due to right ventricular stress. In the others ST depression developed during the transfusion; four showed evidence of cardiac failure and two of them eventually died. The transfusion was abandoned in three.

T Wave. Persistent flattening or inversion of the $T$ wave occurred during seven transfusions and as a transient change in six others. These were mostly unassociated with other clinical or electrocardiographic abnormalities. In one baby marked inversion of the $T$ wave was probably related to anoxia (see below). Spiking of the $\mathrm{T}$ wave occurred in one fatal case (se below).

Effect of Calcium. Injection of calcium gluconate rarely produced any change (Fig. 7) in the electrocardiogram. Only seven records show any significant effects, and these consisted of slight bradycardia and prominence or reversion of inverted $T$ waves. QT changes were not seen except in the babies with generally abnormal complexes.
Effect of Digoxin. No changes attributable to digoxin could be detected in the three babies to whom the drug was given.

Exchange Transfusion in Babies under $2,500 \mathrm{~g}$. Abnormalities in the electrocardiogram were most common in this group (see Table 3), but there was no characteristic feature of prematurity.

\section{Case Reports}

Case 17. This $3.7 \mathrm{~kg}$. West Indian infant had severe cardiac failure and erythroblastosis due to rhesus antibodies and was given an exchange transfusion 10 hours after birth (Fig. 8), when $80 \mathrm{ml}$. of blood were removed initially to lower the venous pressure. After $100 \mathrm{ml}$. had been exchanged, the electrocardiogram showed widening and notching of the QRS complex but returned to normal after a brief pause and further venesection of $20 \mathrm{ml}$. The abnormality recurred when the exchange transfusion was resumed and the procedure was then abandoned. The following day a full electrocardiogram showed right bundle-branch block. The infant's condition improved steadily, but he suddenly collapsed and died on the sixth day. Autopsy revealed pulmonary infarcts and also infarction of the spleen and left kidney; there was right ventricular cardiac hypertrophy but no septal defects and histological examination did not add to the macroscopic findings. In retrospect, multiple infarction was thought to have resulted from rapid haemolysis and pulmonary infarction was evident in a pretransfusion chest radiogram.

Case 24. This baby was born by spontaneous vertex delivery at 26 weeks' gestation and weighed $850 \mathrm{~g}$. (1 lb. $14 \mathrm{oz}$.) on the third day. An exchange transfusion was performed on the sixth day, when the plasma bilirubin was $26.6 \mathrm{mg}$. per $100 \mathrm{ml}$. The procedure was carried out in an incubator, using fresh donor blood in $5 \mathrm{ml}$. cycles to a total of $140 \mathrm{ml}$. out and $135 \mathrm{ml}$. in. Frequent attacks of apnoea and bradycardia occurred throughout the 90-minute procedure. At the end of the transfusion, a particularly long attack was immediately terminated by the intravenous injection of $65 \mathrm{mg}$. nikethamide in $5 \mathrm{ml}$. of $5 \%$ dextrose solution. The electrocardiogram (Fig. 9), which had shown bradycardia and flat $T$ waves, reverted to normal and the $T$ waves became upright as a result of the improved oxygenation. Twelve hours after the exchange transfusion, the plasma bilirubin was $12 \mathrm{mg}$. per $100 \mathrm{ml}$. and the jaundice 


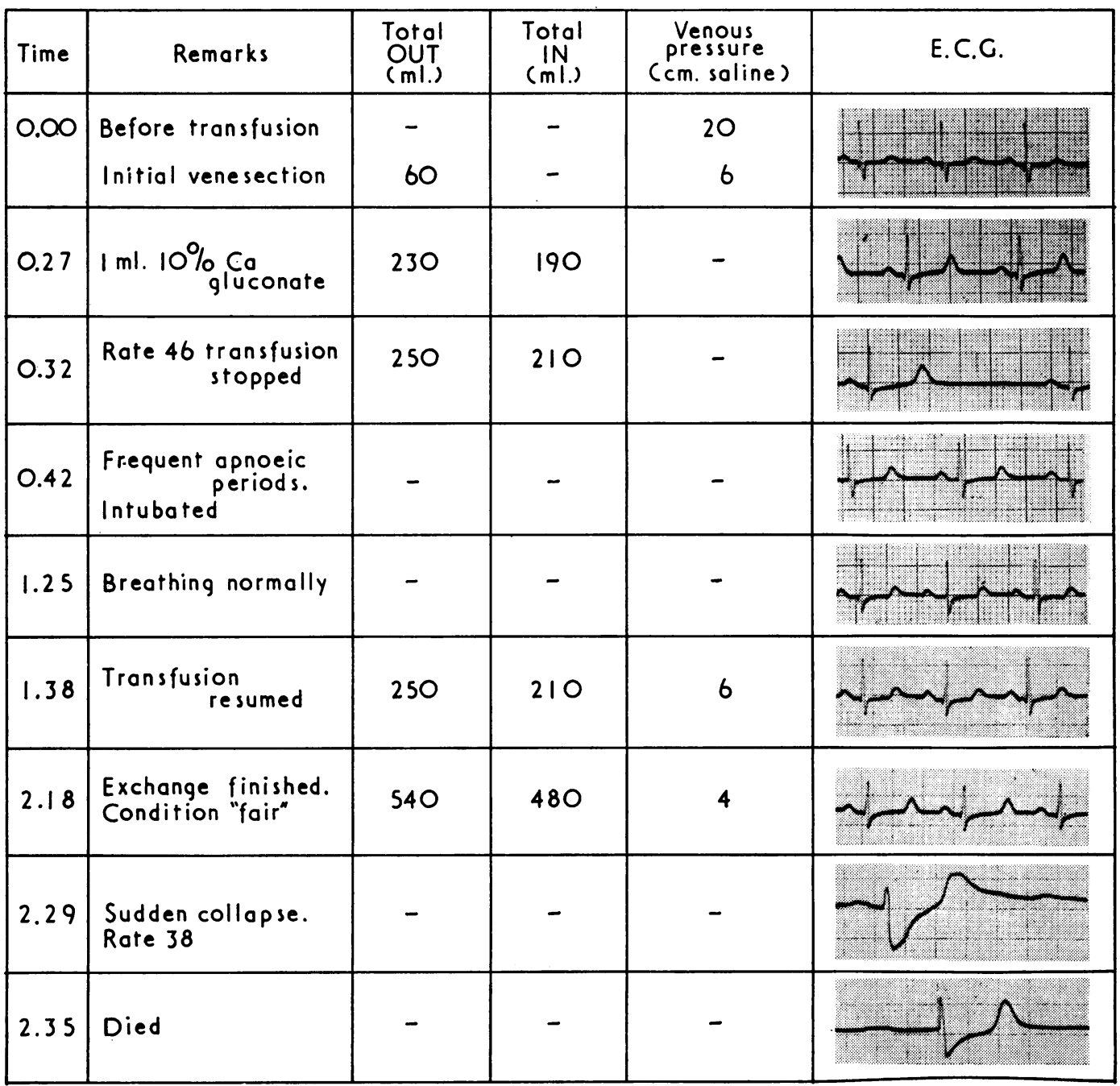

FIG. 6.-Case 13. Lead II. The changes are consistent with a raised serum potassium, but no estimations were made.

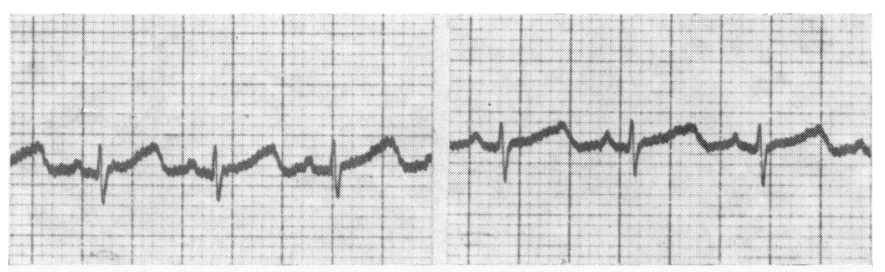

(a)

(b)

FIG. 7.-Case 7. Lead II: (a) before and (b) after intravenous injection of $1 \mathrm{ml}$. of $10 \%$ calcium gluconate. There is no significant change 


\begin{tabular}{|c|c|c|c|c|c|}
\hline Time & Remarks & $\begin{array}{l}\text { Total } \\
\text { OUT } \\
\text { (ml.) }\end{array}$ & $\begin{array}{l}\text { Total } \\
\text { IN } \\
\text { (ml.) }\end{array}$ & \begin{tabular}{|c|} 
Venous \\
pressure \\
(cm. saline) \\
\end{tabular} & E.C.G. \\
\hline 0.00 & $\begin{array}{l}\text { Before start of } \\
\text { transfusion }\end{array}$ & - & - & 12 & The cus \\
\hline 0.05 & Initial venesection & 80 & - & 1 & 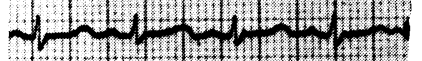 \\
\hline 0.25 & $0.125 \mathrm{mg}$. digoxin i.v. & 180 & 100 & - & \\
\hline 0.26 & & 180 & 100 & 5 & \\
\hline 0.30 & $\begin{array}{l}\mid \mathrm{ml} .10 \% \text { _calcium } \\
\text { gluconate i.v. }\end{array}$ & 200 & 100 & 0 & oje \\
\hline 0.35 & Transfusion resumed & 200 & 100 & 0 & mantum \\
\hline 0.40 & & 240 & 160 & 0 & \\
\hline 0.50 & Transfusion stopped & 260 & 180 & 0 & \\
\hline 1.05 & $\begin{array}{c}\text { Transfusion abandoned. } \\
\mathrm{Hb} 99 \%\end{array}$ & 260 & 180 & $\mathrm{O}$ & \\
\hline
\end{tabular}

Fig. 8.-Case 17 (see text). Changes are consistent with dilatation of the right heart.

\begin{tabular}{|c|c|c|c|c|c|c|}
\hline Time & Remarks & $\begin{array}{l}\text { Total } \\
\text { OUT } \\
\text { (ml.) }\end{array}$ & $\begin{array}{l}\text { Total } \\
\text { IN } \\
\text { (m|.) }\end{array}$ & $\begin{array}{c}\text { Venous } \\
\text { pressure } \\
\text { (cm. saline) }\end{array}$ & Rote & E.C.G. \\
\hline 0.00 & Before start of transfusion & - & - & 5 & 115 & 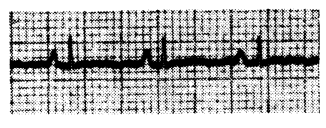 \\
\hline $1 \cdot 25$ & Marked periodic breathing & 130 & 125 & - & 60 & 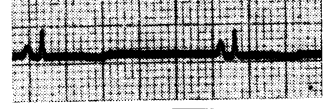 \\
\hline $1 \cdot 30$ & $\begin{array}{l}\text { End of exchange } \\
\text { transfusion. } \\
\text { Frequent apnoeo }\end{array}$ & 140 & 135 & 5 & 96 & 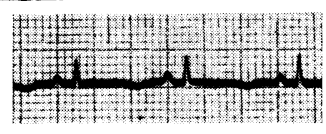 \\
\hline $1 \cdot 31$ & $\begin{array}{l}65 \mathrm{mg} . \text { nikethamide in } 5 \mathrm{ml} \text {. } \\
5 \% \text { dextrose given i.v. }\end{array}$ & 145 & 140 & - & 90 & \\
\hline
\end{tabular}

F1G. 9.-Case 24. Lead II. The relation of bradycardia to apnoea. Respiratory stimulation with nikethamide resulted in upright $\mathbf{T}$ waves. The changes are consistent with improved oxygenation. 
gradually subsided. Her weight, which was $1 \mathrm{lb} .12 \mathrm{oz}$. (793 g.) on the day of transfusion, fell to $1 \mathrm{lb} .9 \mathrm{oz}$. (708 g.), after which she thrived steadily. She was last seen aged 21 months when she was completely normal.

\section{Discussion}

With so much at stake, it is surprising that a more efficient method of monitoring the heart has not yet been universally adopted. Previous reports on the electrocardiographic changes during exchange transfusion are surprisingly few and are mainly concerned with the effects of potassium, calcium and citrate blood levels in comparatively small series. Electrocardiographic monitoring was recommended by Joos, Yu and Miller (1954) who reported instances of bradycardia, A-V block and a prolonged QT interval associated with low ionized serum calcium levels in 10 infants. Depression of the ST segment, elevation of the $T$ wave, ventricular fibrillation and other forms of arrhythmia have also been described (Furman, Hellerstein and Startzman, 1951). Taylor, Gillis, Nash and Kullman (1961) showed the relation of ventricular fibrillation to potassium and cold in experimental transfusions in rabbits. Recently Montgomery, Vallbona, Hill, Rush and Coleman (1961) reported variations in heart rate but did not comment on other electrocardiographic changes during exchange transfusion.

In the past three years our routine use of the electrocardiogram for monitoring the heart has provided a larger series for analysis than those previously reported. Nevertheless, a comparison of the findings is not valid since special precautions were taken to reduce or avoid all known hazards. For instance, the changes of hypocalcaemia, formerly stressed, are now avoided by routine calcium administration. Similarly, the transfusion was stopped or abandoned if the heart rate varied outside the range of $100-160$, or if abnormal complexes appeared.

Our observations are limited in that only a single lead was available for analysis. Elevation of the $\mathbf{P}$ wave and slight tachycardia were the commonest changes encountered and were probably due to an increase in right atrial pressure. Slight decrease in the height of the $T$ wave was also considered relatively benign. The serious alterations included bradycardia, widening, notching or low voltage of the QRS complex, ST deviation and increased height of the $T$ wave. These changes probably arose from a combination of mechanical and biochemical factors and indicate severe ventricular embarrassment. Their appearance may herald impending danger and it is inadvisable to continue the transfusion until the electrocardiogram has returned to normal.
Bradycardia or tachycardia has always been recognized as being of serious significance. Counting the heart rate is usually done with the stethoscope chest piece strapped over the praecordium. Although this has the virtue of simplicity, the method suffers from several disadvantages. Rapid changes, soft beats, dislodgement of the chest piece or unfamiliarity with the stethoscope may result in serious inaccuracies. Hon (1958), using tape-recorded foetal heart rates, showed observer errors of as much as 70 beats per minute even with experienced staff. Equally important is the fact that the heart rate may sometimes remain unchanged despite evidence of imminent failure.

Death during exchange transfusion is particularly tragic, not only for the loss of a potentially normal baby but also because the chances of having a live baby decrease with subsequent pregnancies. The increasing use of exchange transfusion for hyperbilirubinaemia of prematurity means that a further group of relatively poor risk cases must be considered. All are agreed that one of the most important factors in the overall success is the experience of the operator. Electrocardiographic monitoring is no substitute for this but, by providing early and accurate warning of impending danger, the method is a valuable addition to the technique of exchange transfusion.

\section{Summary}

Thirty consecutive exchange transfusions with electrocardiographic monitoring were performed on 17 normal and 10 premature infants.

The commonest changes were transient tachycardia, elevation of the $\mathrm{P}$ wave and flattening or inversion of the $T$ wave. These were more frequent in premature babies and are considered relatively benign.

More serious changes indicating ventricular embarrassment were bradycardia of less than 100 per minute, widening, notching and low voltage of the QRS complex, ST deviation and spiking of the $T$ wave.

The electrocardiograph is an accurate monitor of the heart rate and may give warning of danger when the heart rate is unchanged. Its routine use is recommended during all exchange transfusions.

We would like to thank Dr. B. D. R. Wilson and Dr. Dennis Cottom for their helpful advice. Thanks are also due to Miss M. Harper of the Photographic Department for the illustrations and to the students and nurses of St. Thomas's and the Lambeth Hospitals for their help during the actual exchanges. 
Appendix

Since this paper was prepared we have had further experience with 10 more exchange transfusions.

Changes in the electrocardiogram were similar to those we have already described (see Appendix Fig. below). One case is worthy of special comment as it shows changes not previously encountered.

Baby C. This $7 \mathrm{lb} .(3 \cdot 17 \mathrm{~kg}$.) baby was delivered at 37 weeks following artificial rupture of the membranes for rising maternal antibodies. The cord haemoglobin was $66 \%$ and the Coombs' test strongly positive. He showed early signs of congestive cardiac failure. An exchange transfusion was begun two and a half hours later. After $100 \mathrm{ml}$. had been exchanged slight elevation of the ST segment was noticed in the electrocardiogram without any significant change in rate. This rapidly became more marked and the transfusion was stopped. At this time there had been a technical difficulty and air may have entered the catheter. He was carefully examined but his condition was satisfactory. After 28 minutes the electrocardiogram had returned to normal and the transfusion was cautiously resumed. After $440 \mathrm{ml}$. had been exchanged his condition gradually deteriorated. He became lethargic, slightly blue, felt cold $\left(96 \cdot 4^{\circ}\right.$ F. $\left(35 \cdot 8^{\circ}\right.$ C. $\left.)\right)$ and vomited once. The procedure was therefore abandoned. The electrocardiogram had not altered during this latter period.

\begin{tabular}{|c|c|c|c|c|c|c|}
\hline Time & Remorks & $\begin{array}{l}\text { Total } \\
\text { OUT } \\
\text { (ml.) }\end{array}$ & $\begin{array}{l}\text { Totol } \\
\text { IN } \\
\text { (ml.) }\end{array}$ & \begin{tabular}{|c|} 
Venous \\
pressure \\
(cm. saline)
\end{tabular} & Rote & E.C.C. \\
\hline 0.00 & $\begin{array}{l}\text { Before transfusion } \\
\text { Initial venesection }\end{array}$ & $\begin{array}{l}- \\
40\end{array}$ & $\begin{array}{l}- \\
-\end{array}$ & $\begin{array}{r}10 \\
5\end{array}$ & $\begin{array}{l}112 \\
112\end{array}$ & 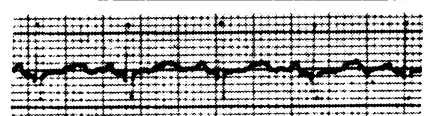 \\
\hline 0.08 & & 60 & 40 & - & 124 & 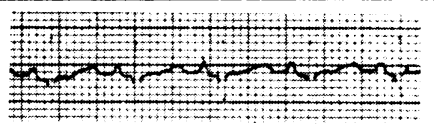 \\
\hline 0.17 & Condition unchanged & 100 & 60 & - & 112 & 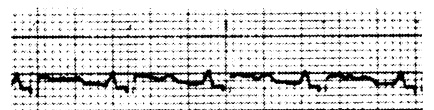 \\
\hline 0.20 & $\begin{array}{l}\text { Transfusion stopped. } \\
\text { Condition unchanged }\end{array}$ & 100 & 72 & 5 & 124 & 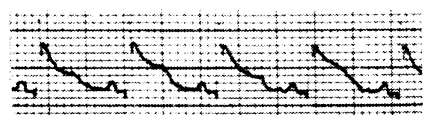 \\
\hline 0.27 & Clinically satisfactory & - & - & 5 & 136 & 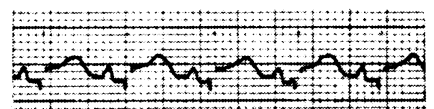 \\
\hline 0.31 & -do- & - & - & - & 112 & 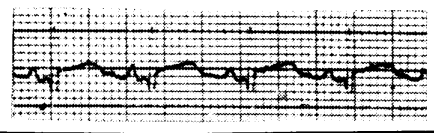 \\
\hline 0.40 & -do- & - & - & 5 & 124 & 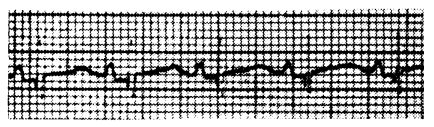 \\
\hline 0.48 & Transfusion resumed & - & - & 5 & 118 & 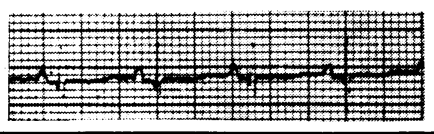 \\
\hline $1 \cdot 39$ & $\begin{array}{l}\text { Transfusion } \\
\text { abandoned } \\
\text { Cold, blue, lethargic }\end{array}$ & 440 & 400 & - & 136 & 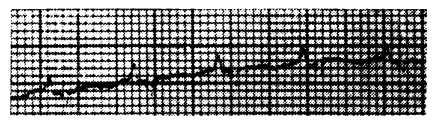 \\
\hline
\end{tabular}

These changes are consistent with coronary ischaemia and could have been caused by an air embolus. 
He then improved quickly and a repeat exchange transfusion 18 hours later was uneventful. When last seen aged 6 weeks he was a normal thriving baby.

In retrospect these changes were consistent with transient coronary ischaemia caused by air embolism.

\section{REFERENCES}

Allen, F. H. and Diamond, L. K. (1957). Erythroblastosis foetalis. New Engl. J. Med., 257, 659, 705 and 761

Boggs, T. R. and Westphal, M. C. (1960). Mortality of exchange transfusion. Pediatrics, 26, 745 .

Farquhar, J. W. and Smith, $H$. (1958). Clinical and biochemical changes during exchange transfusion. Arch. Dis. Childh., 33, 142 .
Furman, R. A., Hellerstein, H. K. and Startzman, V. V. (1951) Electrocardiographic changes occurring during the course of replacement transfusions. J. Pediat. 38, 45.

Hon, E. H. (1958). The electronic evaluation of the fetal heart rate.

Amer. J. Obstet. Gynec., 75, 1215.
Joos, H. A. Yu, P. N. and Miller, G. (1954). Electrocardiographic changes during replacement transfusion. A.M.A. Amer. J. Dis. Child., 88, 471 .

Montgomery, J. R., Vallbona, C., Hill, R. M., Rush, J. R. and Coleman, G. (1961). Continuous monitoring of the heart rate during exchange transfusion. Amer. J. Dis. Child., 102, 557.

van Praagh, R. (1961). Causes of death in infants with hemolytic disease of the newborn (erythroblastosis fetalis). Pediatrics, 28, 223.

Taylor, W. C., Gillis, C. N., Nash, C. W. and Kullman, G. L. (1961). Experimental observations on cardiac arrhythmia during exchange transfusion in rabbits. J. Pediat., 58, 470.

Tovey, G. H. and Valaes, T. (1959). Prevention of stillbirth in rh haemolytic disease. Lancet, $2,521$. 